\title{
Observations on Corynebacteria and Related Pleuropneumonia-like Organisms (PPLO)
}

\author{
By PHYLLIS PEASE AND NANCY LAUGHTON \\ Department of Bacteriology, University of Birmingham
}

(Received 28 December 1960)

\begin{abstract}
SUMMARY
Morphological, cultural and serological evidence is presented to suggest that a relationship exists between corynebacteria of human vaginal origin and pleuropneumonia-like organisms (PPLO). It is concluded that many PPLO are L-forms of corynebacteria, and that the differences between these and the L-forms of Gram-negative bacteria, most commonly studied, are in conformity with the differences between the parent bacterial forms.
\end{abstract}

\section{INTRODUCTION}

Numerous workers have reported an association between pleuropneumonia-like organisms (PPLO) and strains of corynebacteria (Minck, 1953; Wittler, Cary \& Lindberg, 1956; Smith, Peoples \& Morton, 1957), and have adduced evidence that the former may become transformed into the latter. The PPLO studied by Wittler et al. was found to be serologically related to a corynebacterium isolated from the same source, the human genital tract. The present study was initiated as a result of observations made on two types of colony, which arose in the same cultures of a corynebacterium isolated from a pathological condition; one was bacterial and the other resembled a PPLO. Each was capable of transformation into the other, and they appeared, in fact, to be different phases of the same organism. These transformations occurred, regularly but infrequently, in the course of investigations concerned with their pathogenicity, which involved their artificial culture on solid and in liquid medium and in embryonated eggs. The PPLO was identified as such because of its morphological, cultural and serological characters (see Discussion for references). The bacterium closely resembled the organism isolated from the human cervix uteri and named Corynebacterium cervicis (Laughton, 1951, 1954). In an attempt to elucidate the relationship between them, observations were made upon both these forms, and upon human genital tract PPLO isolated in this and other laboratories.

\section{METHODS}

Organisms. The first corynebacterium and the PPLO were obtained, by the courtesy of Dr K. B. Rogers, as primary isolation cultures taken at post-mortem from the lungs of a baby showing the condition known as hyaline membrane; the cultures consisted of a chocolate agar plate bearing both types of colony, and a blood plate with the PPLO colonies only. This original strain of the corynebacterium and those subsequently derived from the PPLO were identified as Corynebacterium cervicis (Laughton, 1951, 1954) by their morphology, cultural reactions 
and serological reactions. Other PPLO isolated in this laboratory were obtained by the direct inoculation of Difco PPLO medium and chocolate agar with vaginal swabs taken at a Birmingham V.D. clinic by Miss D. M. Shotton. In cases where the plates were heavily contaminated with other organisms, a piece of filter paper, soaked in a solution containing 200 units penicillin/ml., was placed on the medium subsequently used to obtain pure cultures of PPLO. One PPLO was obtained by dissociation from a strain of corynebacterium also isolated from a vaginal swab. Four strains of Mycoplasma hominis Type 1 (H50R, H 26, H23, D419) and one of M. hominis Type 2 (strain Campo originally isolated by Dr Dienes) were obtained by courtesy of Dr D. G. ff. Edward (Wellcome Research Laboratories, Beckenham) and used for purposes of comparison.

Cultural methods. Embryonated eggs were inoculated via the yolk sac and the intravenous and amniotic routes. All inocula were checked for purity and viability by plating concurrently upon artificial media. Control eggs in each series were inoculated with the corresponding suspension fluid without organisms. Media used were Difco PPLO medium and chocolate agar, and Hartley's broth with $10 \%$ (v/v) human plasma or horse serum. Fermentation reactions of the PPLO were tested in a blood broth (made by adding $2 \%, \mathrm{v} / \mathrm{v}$, horse blood cells and $0.5 \%$, w/v, oxoid yeast extract to nutrient broth, steaming, filtering, adjusting to $\mathrm{pH} 7 \cdot 8$ and then autoclaving) with $20 \%(\mathrm{v} / \mathrm{v})$ de-activated horse serum and $1.0 \%(\mathrm{w} / \mathrm{v})$ carbohydrate; the $\mathrm{pH}$ values were taken by means of a capillator after 1,2 and 3 weeks. The fermentation reactions of the corynebacteria were tested in serum water sugar media.

Serology. Antisera were prepared in rabbits by the intravenous injection of suspensions made up to an opacity of a No. 10 Brown's opacity tube of bacteria, and of PPLO in $\mathbf{0 . 2} \%(\mathrm{v} / \mathrm{v})$ formal saline. Five weekly courses of three $2 \mathrm{ml}$. doses were given. Some preliminary complement-fixation tests were performed, but these were subsequently abandoned in favour of gel diffusion tests, which proved to be more convenient and informative. To prepare the bacterial antigen for the complement-fixation tests, suspensions of the bacteria were made in $0.5 \mathrm{ml}$. of $0.01 \mathrm{~N}$-sodium carbonate, $0.05 \mathrm{~g}$. trypsin (Difco) added, and the mixture incubated for $18 \mathrm{hr}$. at $37^{\circ}$, after which $1 \mathrm{ml}$. of acid ethanol (95 vol. absolute ethanol $+5 \mathrm{vol}$. $2 \mathrm{~N}$-hydrochloric acid) was added. The mixture was centrifuged and the deposit washed several times in saline to neutralize it. The deposit was then made up to an opacity of a No. 10 Brown's opacity tube. The PPLO antigen for the complementfixation tests consisted of saline suspension made up to an opacity of a No. 2 Brown's opacity tube. Complement was titrated before each test and each test was set up in triplicate, with a suitable range of dilutions, usually $2,2.5$ and 3 minimal haemolytic doses. All appropriate controls were set up in each test. The antigens used for the gel diffusion tests consisted of bacterial and PPLO saline suspensions of four times the strength of those used for the production of antisera and, in some cases, were supersonically disintegrated. The tests were made by double diffusion precipitation in agar/phosphate gel at $\mathrm{pH} 7 \cdot 4$. To avoid false cross-reactions, bacteria for serum production were grown on glucose agar, and PPLO on media with horse serum. For test antigens, PPLO were grown on media with human plasma.

Electron microscope examinations. The electron microscope used was a Metropolitan Vickers E.M. 3, and all the preparations were gold + palladium shadowed. 
The organisms except for the transition stages were grown upon collodion membranes for various periods of time before mounting. The preparations of the transition stages were obtained by impressing agar blocks containing the transforming organisms on to collodion membranes. Gentle pressure was applied, and the blocks were removed 3-4 hr. later. The membranes were then mounted.

\section{RESULTS}

In the early observations, two types of colony, the bacterial and the PPLO from the original cultures, were subcultured on chocolate agar and thence into Robertson's meat broth. On chocolate agar, both types of colony grew unchanged in subcultures; but subcultures on chocolate agar from the meat broth cultures inoculated with the PPLO alone, after these had been stored for 6 weeks at $4^{\circ}$, gave evidence of transformation to the bacterial phase. When replated upon chocolate agar these cultures gave rise to colonies both of the PPLO and of a corynebacterium resembling the original strain. The cultures inoculated with the bacteria alone showed only bacterial colonies on replating on this occasion but subsequently these were also observed, after the same procedure, to give rise to PPLO colonies; and on repeated subculture on chocolate agar from chocolate agar, over an extended period of time, the bacterial colonies gave rise to both types on approximately twelve occasions, and to PPLO colonies alone on one.

Transformation of the PPLO to the corynebacterium was observed, in artificial culture, only after subculture in fluid medium; this occurred on two occasions, after the lapse of a year from the time of the first observations, during which time the PPLO had been subcultured on chocolate agar, at intervals of from ten to fourteen days, without any sign of reversion. On one occasion the transformation was occasioned, as before, by storage in meat broth at $4^{\circ}$ for several weeks, on the other simply by subculture in liquid yeast-extract medium. On both occasions, subculture on chocolate agar gave both types of colony.

In order to eliminate any question of contamination, repeated efforts were made, without success, to isolate similar PPLO from the mouths and noses of the operators and their associates.

It was discovered that these transformations occurred more frequently on culture in embryonated eggs than on artificial media; the results of these experiments are shown in Table 1. Cultures from control eggs showed no sign of any comparable organisms.

The results of fermentation tests showed that the PPLO did not ferment any of the carbohydrates examined, nor did 3 out of the 6 strains of the corynebacterium tested; a further 3 strains of the corynebacterium were found to ferment, irregularly, glucose, lactose, sucrose, dextrin, maltose, and starch, but not mannitol, dulcitol or salicin.

The results of complement-fixation tests are summarized in Table 2. The antigens used were the PPLO and corynebacterium as first isolated, and variants of Corynebacterium cervicis maintained in this laboratory. The sera used were those prepared against the original corynebacterium and PPLO, and the ' 9 ' $\mathrm{T}$ ' variant of $C$. cervicis. The results show a relationship between the PPLO and both strains of corynebacterium. A control serum, prepared against a species of actinomyces, gave negative reactions. 
At a considerably later date, a strain of corynebacterium, resembling but not identical with, Corynebacterium cervicis, also from the vagina, when grown in the vicinity of 200 units penicillin/ml., absorbed on a strip of filter paper on the surface of Difco PPLO medium with $3.5 \%$ added sodium chloride, was found regularly to dissociate and produce an L-form or PPLO which was serologically related to the other PPLO examined (Table 3). This PPLO was unstable, except in the presence of penicillin, and reverted readily to the bacillary form.

\section{Table 1. Results of cultivation in embryonated eggs}

The eggs were 5-6 days old for the yolk sac, and 10-12 days for other routes. Subcultures were made after 1 to 4 days, according to the viability of the embryo.

\begin{tabular}{|c|c|c|c|}
\hline $\begin{array}{l}\text { Inoculum and } \\
\text { no. of eggs }\end{array}$ & $\begin{array}{l}\text { Route of } \\
\text { inoculation }\end{array}$ & $\begin{array}{c}\text { Material } \\
\text { subcultured }\end{array}$ & $\begin{array}{l}\text { Organisms recovered } \\
\text { on subculture }\end{array}$ \\
\hline $\begin{array}{c}\text { Corynebacterium } \\
9\end{array}$ & Yolk sac & Yolk & $\begin{array}{l}1 \text { PPLO only } \\
2 \text { PPLO and corynebacterium } \\
6 \text { corynebacterium only }\end{array}$ \\
\hline $\begin{array}{l}\text { Corynebacterium } \\
6\end{array}$ & Intravenous & $\begin{array}{l}\text { Lung, liver } \\
\text { amniotic fluid }\end{array}$ & $\begin{array}{l}1 \text { PPLO and corynebacterium } \\
1 \text { no organisms recovered } \\
4 \text { corynebacterium only }\end{array}$ \\
\hline $\begin{array}{c}\text { Corynebacterium } \\
6\end{array}$ & Amniotic & $\begin{array}{l}\text { Tracheal } \\
\text { washings and } \\
\text { lung }\end{array}$ & 6 corynebacterium only \\
\hline PPLO 6 & Yolk sac & Yolk & 6 PPLO only \\
\hline PPLO 19 & Amniotic & $\begin{array}{l}\text { Tracheal } \\
\text { washings and } \\
\text { lung }\end{array}$ & $\begin{array}{l}18 \text { PPLO only } \\
1 \text { PPLO and corynebacterium }\end{array}$ \\
\hline
\end{tabular}

The results of gel diffusion tests on all these strains are shown in Table 3. The antigens were the original corynebacterium, after 2 years' subculture, the original PPLO (0), PPLO $(1,2,3,4,5)$ isolated in this laboratory, and 5 strains of human PPLO supplied by Dr D. G. ff. Edward. The sera were prepared against the original PPLO (0); one of those isolated in this laboratory, PPLO (1); and the penicillininduced dissociant, PPLO (P). The results given by this method were very clear-cut,

Table 2. Complement-fixation tests

\begin{tabular}{|c|c|c|c|}
\hline \multirow[b]{2}{*}{ Antigen } & \multicolumn{3}{|c|}{ Antiserum } \\
\hline & $\begin{array}{l}\text { PPLO } \\
\text { phase }\end{array}$ & $\begin{array}{l}\text { Bacterial } \\
\text { phase }\end{array}$ & $\begin{array}{c}\text { Corynebac- } \\
\text { terium } \\
\text { cervicis } 9, " \mathrm{~T} \text { ' }\end{array}$ \\
\hline PPLO phase & 4 & $\mathbf{3}$ & 3 \\
\hline Bacterial phase & 1 & 4 & 1 \\
\hline C. cervicis' 9 , ' $\mathrm{O}$ ' & 3 & 3 & 4 \\
\hline C. cervicis $\mathbf{9}$, ' $\mathrm{T}$ ' & $\mathbf{3}$ & 4 & 3 \\
\hline
\end{tabular}

Figures indicate degrees of reaction.

and showed a serological relationship between most of the PPLO tested, whether these were associated with corynebacteria or had been isolated independently in this laboratory or elsewhere, with the exception of the Campo strain. The corynebacterial phase reacted with the PPLO sera, but a serum prepared against that 
phase reacted only with the homologous antigen, presumably because the surface antigens were mainly represented, and were absent from the PPLO.

Preparations for examination with the optical and electron microscopes were made from the corynebacterium colonies, from the PPLO colonies, and from mixtures of the two forms when these had apparently arisen from one form only; that is to say, from plates on which both organisms occurred which had been inoculated with material derived from a pure culture of one form only. The corynebacterium was septate and varied from rods to coccal forms (Pl. 1, fig. 1). Preparations of mixtures of corynebacteria and PPLO, which had apparently arisen from the corynebacteria only showed flat, disk-like bodies, filaments and small granules (Pl. 1, fig. 2, 3).

Table 3. Gel diffusion tests

\begin{tabular}{|c|c|c|c|c|c|c|c|c|c|c|c|c|}
\hline \multirow[b]{3}{*}{ Antisera } & \multicolumn{12}{|c|}{ Antigens } \\
\hline & \multirow{2}{*}{$\begin{array}{l}\text { Bacterial } \\
\text { phase (0) }\end{array}$} & \multirow{2}{*}{$\begin{array}{c}\text { PPLO } \\
(0)\end{array}$} & \multicolumn{5}{|c|}{ PPLO isolates } & \multicolumn{4}{|c|}{ Edward, type 1 PPLO } & \multirow{2}{*}{$\begin{array}{l}\text { Edward, } \\
\text { type } 2 \\
\text { Campo }\end{array}$} \\
\hline & & & 1 & 2 & 3 & 4 & 5 & H 26 & $\mathrm{H}_{23}$ & H5OF & $\widehat{D 419}$ & \\
\hline PPLO (1) & + & + & + & + & + & + & + & + & + & + & + & - \\
\hline PPLO (1) & \pm & + & + & + & + & + & + & + & + & + & + & - \\
\hline PPLO (P) & $\overline{+}$ & + & + & - & - & - & - & + & - & - & - & - \\
\hline
\end{tabular}

After the PPLO had been subcultured regularly on chocolate agar for several months, electron micrographs showed larger, more opaque, bodies which appeared to be capable of breaking down into small particles (Pl. 1, fig. 4). Preparations of mixtures of corynebacteria and PPLO which had apparently arisen from the PPLO alone showed coccal and rod-shaped bacterial forms (Pl. 2, fig. 5, 6, 7) and smaller particles of various sizes ranging down to approximately $0.1 \mu$ in diameter (Pl. 2, figs. 5, 7).

\section{DISCUSSION}

Bacterial L-forms were originally identified with PPLO, and the suggestion that the latter are, in fact, a type of stabilized $\mathrm{L}$-form has often been made (Bisset, 1952; Dienes \& Weinberger, 1951; Tulasne, 1951). Recently, evidence has accumulated to suggest that corynebacteria (Minck, 1953; Wittler et al. 1956; Smith, Peoples \& Morton, 1957) and possibly Haemophilus (Amies \& Jones, 1957) may be related to PPLO of genital tract origin.

The present evidence indicates that one PPLO isolated in association with a strain of Corynebacterium cervicis, and several strains isolated independently from the vagina, are serologically closely related one to another, and to authentic strains of human mycoplasma Type 1 , as well as to this and other strains of $C$. cervicis and to a PPLO or L-form derived from a corynebacterium by the use of penicillin. The PPLO and associated corynebacteria, in both cases, are transformable one to the other, and electron micrographs show the processes of this transformation, as well as the morphology of the PPLO, which are identifiable as such because of their appearance, origin and cultural characters, as well as their serological relationships. They are typical of PPLO, as described by Bordet (1910), Borrel, Dujardin-Beaumetz, Jeantet \& Jouan (1910), Bridré \& Donatien (1923), Cuckow \& KlienebergerNobel (1955), Dienes (1960), Freundt (1960), Klieneberger-Nobel (1954), Laidlaw \& 
Elford (1936), Ledingham (1933), Liebermeister (1960), Nowak (1929), Sabin (1941), Tang, Wei, McWhirter \& Edgar (1935), Turner (1935), Wroblewski (1931). The combination of evidence renders their identity as PPLO unquestionable, but it is also apparent that many characteristics of PPLO are shared with L-forms, and that, in relation to the associated corynebacterium, this PPLO and those of Wittler, Smith and their collaborators, must be regarded as L-forms.

Much argument has been expended upon points of difference between L-forms and PPLO, in respect of stability, fermentation pattern, etc., but it would appear that much opposition to the concept that they are alike is based upon the supposition that the L-forms most frequently studied are in some respect typical, for which there is no logical basis. Since it appears that large numbers of PPLO are closely related it is reasonable to suppose that their parent bacteria are also closely related, and probably many PPLO are L-forms of corynebacteria. It does not appear that the differences between PPLO and the L-forms of Proteus, which is the subject of almost all such comparisons, are greater than, if as great as the differences between Proteus and Corynebacterium. The general conclusion from these observations is that the type of vaginal PPLO, sometimes described as Mycoplasma hominis Type 1, is the L-form of Corynebacterium cervicis. M. hominis Type 2 (Campo) appears to be distinct, but has also been claimed to be associated with a corynebacterium (Smith et al. 1957). The descriptions of the so-called Haemophilus of Amies \& Jones (1957) and Edmunds (1960) suggest that this organism may also be a corynebacterium, and that the origin of vaginal PPLO is relatively uniform.

\section{REFERENCES}

Amres, C. R. \& Jones, S. A. (1957). A description of Haemophilus vaginalis and its L-forms. Canad. J. Microbiol. 3, 579.

Bisset, K. A. (1952). Bacteria. Edinburgh and London: E. and S. Livingstone.

Bordet, J. (1910). La morphologie du microbe de la péripneumonie des bovidés. Ann. Inst. Pasteur, 24, 161.

Borkell, A., Dujardin-Beaumetz, E., Jeantet \& Jouan (1910). Le microbe de la péripneumonie. Ann. Inst. Pasteur, 24, 168.

Bridré, J. \& Donatien, A. (1923). Le microbe de l'agalaxie contagieuse et sa culture in vitro. C. R. Acad. Sci., Paris, 177, 841.

Cuckow, F. W. \& Klieneberger-Nobel, E. (1955). Further studies of the organisms of the pleuropneumonia by electron microscope. J. gen. Microbiol. 13, 149.

Dienes, L. (1960). Controversial aspects of the morphology of PPLO. Ann. N.Y. Acad. Sci. 79, 356.

Dienes, L. \& Weinberger, H. J. (1951). The L-forms of bacteria. Bact. Rev. 15, 245.

Enmunds, P. N. (1960). Haemophilus vaginalis: morphology, cultural characters and viability. J. Path. Bact. 79, 273.

Freund, E. A. (1960). Morphology and classification of the PPLO. Ann. N.Y. Acad. Sci. 79, 312.

Klieneberger-Nobel, E. (1954). The organisms of the so-called pleuropneumonia group. Biol. Rev. 29, 154 .

Laidlaw, P. P. \& Elford, W. J. (1936). A new group of filterable organisms. Proc. Roy. Soc. B, 120, 292.

Laughton, N. (1951). Observations on the bacterial flora of the cervical canal in infertile women with cervical dysfunction. Proc. Soc. Study Fertil. 3, 18.

Laughton, N. (1954). A study of a bacterium isolated from the human cervix. J. Path. Bact. 67, 169. 


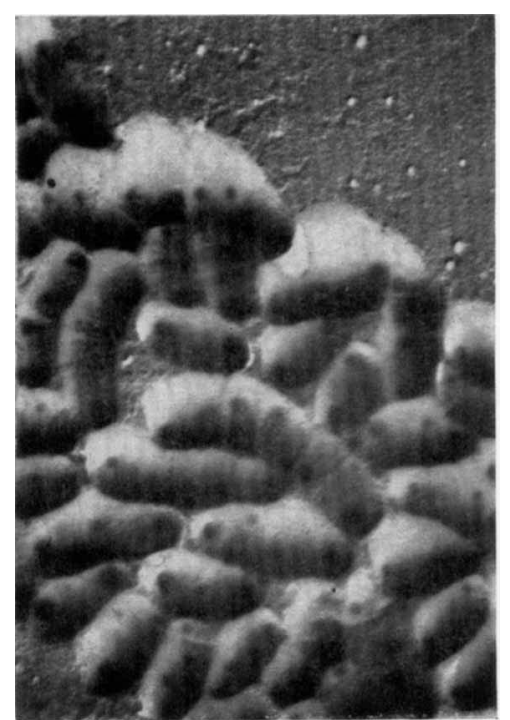

Fig. 1

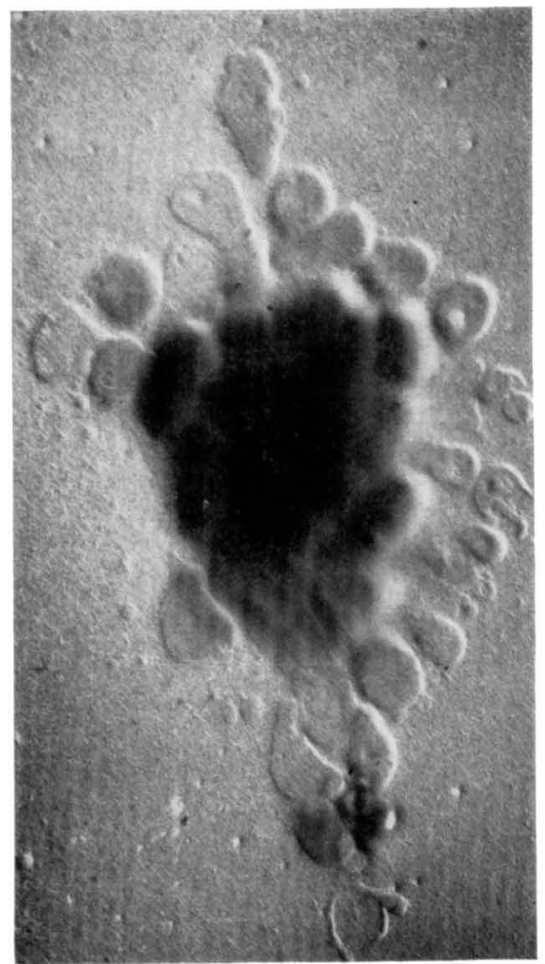

Fig. 2

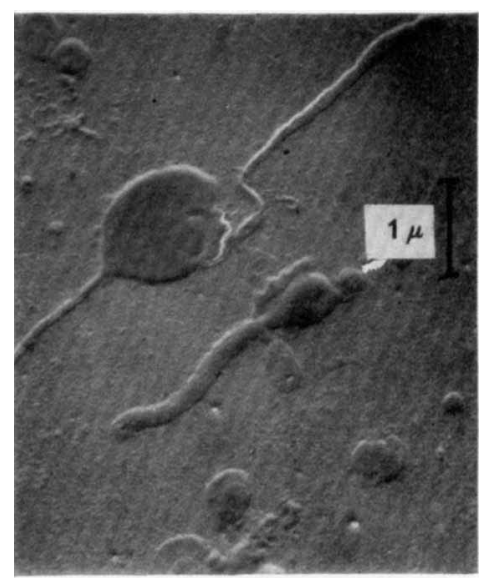

Fig. :3

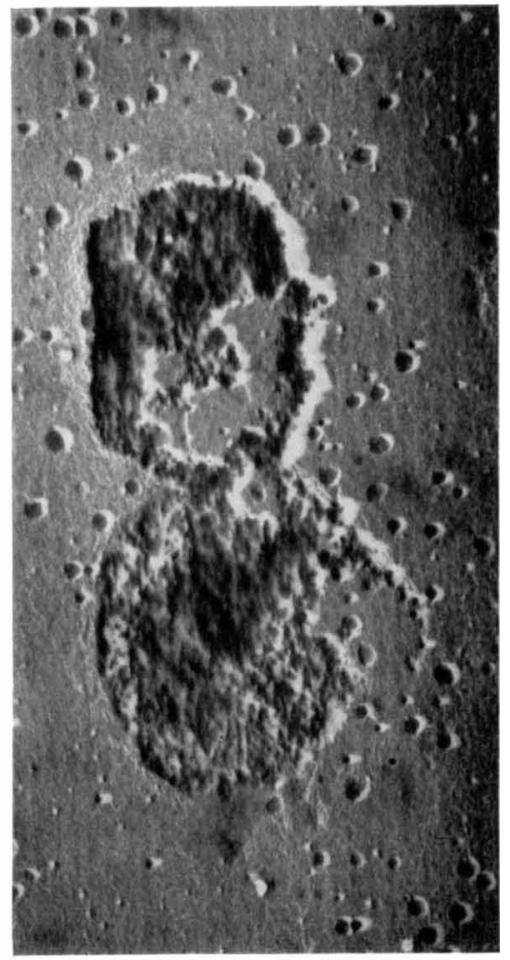

Fig. 4 

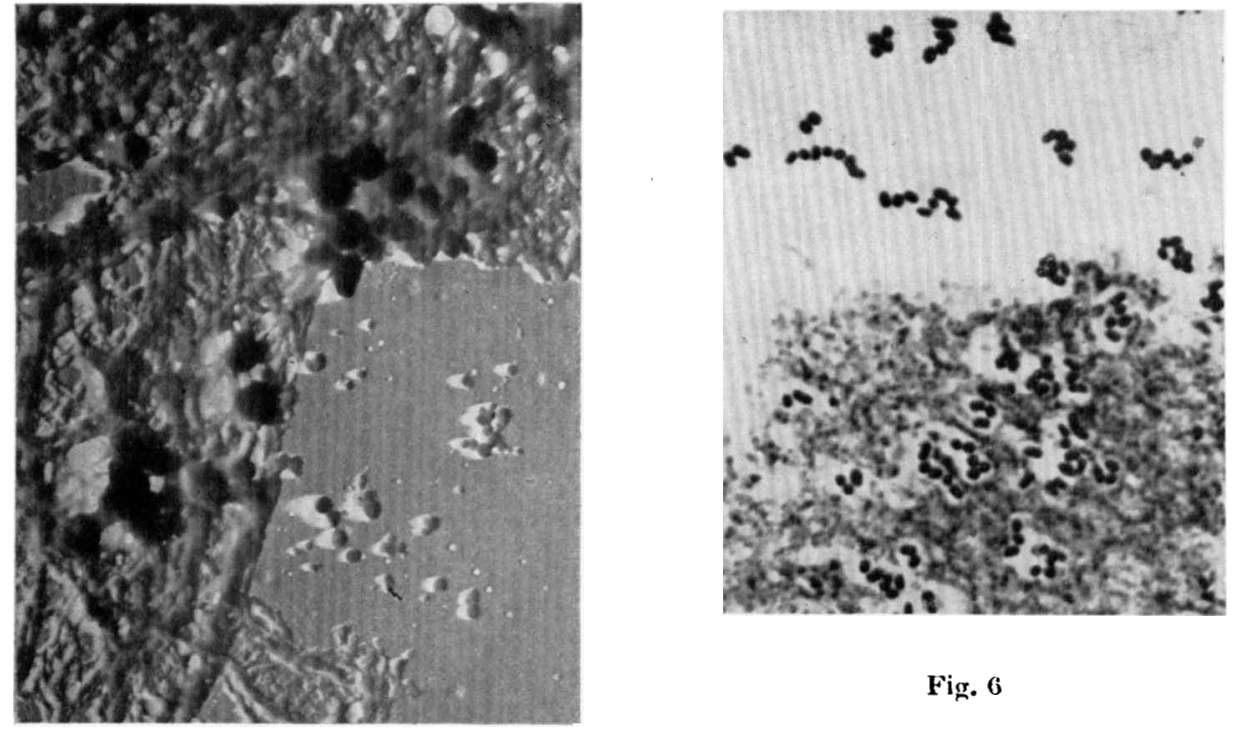

Fig. 6

Fig. :)

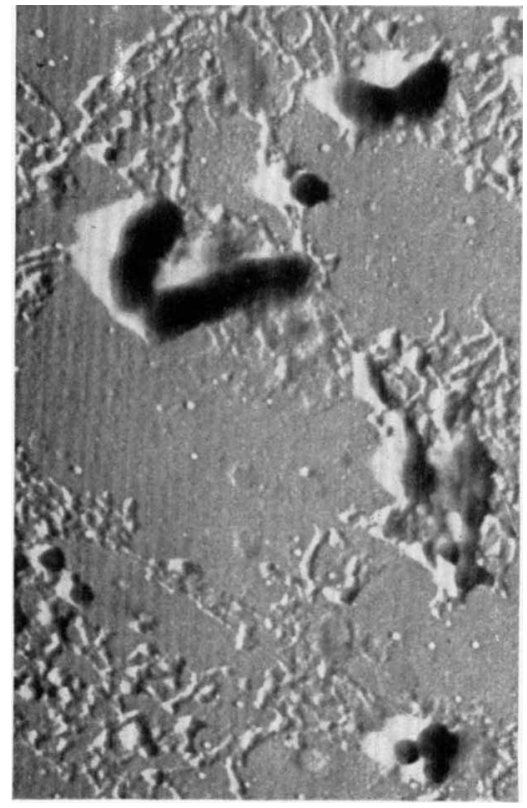

Fig. 7 
LEDINGHAM, J. C. G. (1933). The growth phases of pleuropneumonia and agalactia on liquid and solid media. J. Path. Bact. 37, 393.

Liebermeister, K. (1960). Morphology of the PPLO and L-forms of Proteus. Ann. N.Y. Acad. Sci. 79, 326.

Mınck, R. (1953). Recherches sur l'origine des organisms du type de la péripneumonie trouvés dans les organes génitaux de la femme. C.R. Acad. Sci., Paris, 236, 250.

Nowak, J. (1929). Morphologie, nature et cycle évolutif du microbe de la péripneumonie des bovidés. Ann. Inst. Pasteur, 43, 1330.

SABIN, A. B. (1941). The filterable organisms of the pleuropneumonia group. Bact. Rev. $5,1$.

Smith, P. F., Peoples, D. M. \& Monton, H. E. (1957). Conversion of pleuropneumonialike organisms to bacteria. Proc. Soc. exp. Biol., N.Y. 96, 550.

TANG, F. F., WeI, H., McWhirter, D. L. \& Edgar, J. (1935). An investigation of the causal agent of bovine pleuropneumonia. J. Path. Bact. 40, 391.

'Tulasne, R. (1951). Les formes L des bactéries. Rev. Immunol. 15, 223.

'Turner, A. W. (1935). A study on the morphology and life-cycles of the organism of Pleuropneumonia contagiosa boum (Borrelomyces peripneumonie nov. gen.) by observation in the living state under dark-ground illumination. J. Path. Bact. 41, 1.

WitTler, R. G., CARY, S. G. \& LindBerg, R. B. (1956). Reversion of a pleuropneumonialike organism to a corynebacterium during tissue culture passage. J.gen. Microbiol. 14, 763.

Wroblewsi, W. (1931). Morphologie et cycle évolutif des microbes de la péripneumonie des bovidés et de l'agalaxie contagieuse des chévres et des moutons. Ann. Inst. Pasteur, 47, 94.

\section{EXPLANATION OF PLATES}

Plate 1. Electron micrographs $\times 10,000$.

Fig. 1. Corynebacterium cervicis.

Figs. 2 and 3. Impression preparations from plate inoculated with yolk fluid from egg inoculated with the corynebacterium alone. Fig. 2 shows bacterial forms surrounded by PPLO elements. Fig. 3 shows characteristic PPLO elements. 24 hr. growth.

Fig. 4. PPLO form of Corynebacterium cervicis after several months regular subculture. 3 hr. growth.

\section{Plate 2}

Fig. 5 and 7. Impression preparations from plate inoculated with yolk fluid from an egg inoculated with the PPLO form of Corynebacterium cervicis alone. Fig. 5 shows coccal bacterial forms and smaller particles of various sizes. Fig. 7 shows rod-shaped and coccal bacterial forms and smaller particles. Electron micrographs $\times 10,000$.

Fig. 6. Impression preparation from the same material as that in Figs. 5 and 7 , showing a larger field. Similar rod-shaped and coccal bacterial forms are shown arising within the PPLO material. Photomicrograph. $\times 1800$. 